\title{
Retained Specimens Do Not Contain DNA
}

National Cancer Institute

\section{Source}

National Cancer Institute. Retained Specimens Do Not Contain DNA. NCI Thesaurus.

Code $C 127778$.

An indication that the retained biospecimens do not contain DNA. 